\title{
Integrating plant richness in forest patches can rescue overall biodiversity in human-modified landscapes
}

\author{
Fabiano Turini Farah ${ }^{\mathrm{a}, \mathrm{b}, *}$, Renata de Lara Muylaert ${ }^{\mathrm{c}}$, Milton Cezar Ribeiro ${ }^{\mathrm{c}}$, John Wesley Ribeiro ${ }^{\mathrm{c}}$, \\ Julia Raquel de Sá Abílio Mangueira ${ }^{\mathrm{a}, \mathrm{d}}$, Vinicius Castro Souza ${ }^{\mathrm{e}}$, Ricardo Ribeiro Rodrigues ${ }^{\mathrm{a}}$ \\ ${ }^{a}$ Laboratory of Ecology and Forest Restoration (LERF), Department of Biological Sciences, "Luiz de Queiroz" College of Agriculture, University of São Paulo, Av. Pádua Dias \\ 11, Piracicaba, SP 13418-900, Brazil \\ ${ }^{\mathrm{b}}$ Conservation Biology Laboratory (LABIC), Institute of Biological Sciences, São Paulo State University, Av. 24A 1515, Rio Claro, SP 13506-900, Brazil

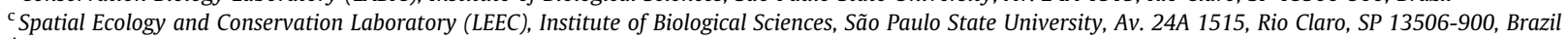 \\ ${ }^{\mathrm{d}}$ Institute of Biology, State University of Campinas, R. Monteiro Lobato 255, Campinas, SP 13083-862, Brazil \\ e Department of Biological Sciences, "Luiz de Queiroz" College of Agriculture, University of São Paulo, Av. Pádua Dias 11, Piracicaba, SP, 13418-900, Brazil
}

\section{A R T I C L E I N F O}

\section{Article history:}

Received 1 December 2016

Accepted 31 March 2017

Available online 3 May 2017

\section{Keywords:}

Forest fragmentation

Anthropogenic landscape

Forest coverage

Vegetal richness

Atlantic Forest

Seasonal forest

\begin{abstract}
A B S T R A C T
The substitution of natural ecosystems with agriculture has led to the establishment of human-modified landscapes globally. In some tropical regions, this process is decades-old, allowing for the study of the effect of such modifications on the remaining biodiversity. However, unlike forest fragments inside regions with extensive primary coverage, the conservation value of ecosystems embedded within intensive farming, i.e., the anthropogenic matrices, has long been ignored, as have the effects of the landscape on such disturbed forest communities. Since the degradation process is predicted to cause the collapse of these fragmented forests, we can choose either to neglect them or to attempt the reversal of the degradation process for biodiversity conservation. Here we investigated the possible influence of landscape predictors on numerous plant species and on the relative proportions of different functional groups. Our results revealed that the richness found in human-modified landscapes had significantly more species than the protected reserves $(+90 \%)$. The distribution of species suggested that any forest patch is likely to harbour a rare species. Generalised linear models and quantile regressions showed that forest cover and connected area influences the persistence of pioneer species and non-pioneer species of the canopy and zoochorics, with the latter also depending on slope. Rarefaction analysis revealed that natural remnants retain many species, even in sites with less than $20 \%$ forest cover. The presence of many zoochoric and non-pioneer canopy species may indicate a qualitative aspect to support conservation-restora tion efforts. These results indicate that the current strategy, which is limited to the preservation of biodiversity in public conservation reserves, should be reconsidered and should include smaller remnants of the natural ecosystem in a regional context and adopt large-scale restoration strategies to preserve the species pool.
\end{abstract}

(c) 2017 Elsevier B.V. All rights reserved.

\section{Introduction}

Conservation studies of forest ecosystems have traditionally been conducted in tropical regions with extensive natural forest cover, particularly primary forests (Gibson et al., 2011; ter Steege et al., 2013). Such studies have also been conducted in wildlife permeable landscapes with large habitat areas; these constitute a favorable scenario for ecological processes in the remaining forest

* Corresponding author at: Laboratory of Ecology and Forest Restoration (LERF), Department of Biological Sciences, "Luiz de Queiroz" College of Agriculture, University of São Paulo, Av. Pádua Dias 11, Piracicaba, SP 13418-900, Brazil.

E-mail address: fbnfrh@gmail.com (F.T. Farah). patches (Norden et al., 2009; Pardini et al., 2009). However, human-modified landscapes often house numerous relatively small remnants of ecosystems that deserve a closer look. These ecosystems can be of great importance for the conservation of soil and water resources (Ehrlich, 2008; Neary et al., 2009; Rey Benayas and Bullock, 2012; Zhang et al., 2001). Moreover, they may harbour important gene pool sets, and if properly protected, can contribute to the conservation of biodiversity (Chazdon et al., 2009b; Tscharntke et al., 2012) by preventing the mass extinction of species (Wright and Muller-Landau, 2006), as well as contributing to ecological restoration (Krauss et al., 2013; Rodrigues et al., 2009; Tambosi et al., 2014). Furthermore, secondary forests are important for the global carbon cycle (Martin et al., 2013; Pan et al., 
2011; Poorter et al., 2016), as even small remnants of ecosystems will take on increasing importance once the current global network of reserves for conservation becomes insufficient to effectively offset predicted global climate changes (Lee and Jetz, 2008; Putz et al., 2001).

As the result of extensive fragmentation and the limited areas of the remaining patches, a large number of tropical forest ecosystems are threatened, especially since these are highly disturbed (Arroyo-Rodríguez et al., 2013; Solar et al., 2015; Turner and Corlett, 1996). The conservation value of these remaining forest patches varies with the type of species present, since many are naturally restricted to mature forests because they depend on environmental conditions found basically in conserved ecosystems (Wright, 2005; Oliveira et al., 2008); their presence may depend largely on the intensity of the disturbance of the surrounding agricultural matrix (Sodhi et al., 2010). Even though many of the landscapes in tropical regions are dominated by agriculture, frequently monocultures, and natural remnants are often disconnected (Chazdon et al., 2009a; Tabarelli et al., 2010)- the ecosystems have not yet become classical secondary forests (Barlow et al., 2007; Van Breugel et al., 2013). They may be declining old-growth forests, with a vegetation structure still containing elements resistant to fragmentation, such as long-lived trees (Metzger et al., 2009; Farah et al., 2014). Although the negative impacts of habitat loss in landscapes dominated by monocultures on biodiversity are clear (Immerzeel et al., 2014; Karp et al., 2012), secondary or old-growth remnant forests can still preserve an important and often overlooked richness, maintaining much of the regional flora and fauna (Arroyo-Rodriguez et al., 2009; Dahal et al., 2014; Dent and Wright, 2009). In regions with only small amounts of native forest cover, these remaining forests should be considered in policies for conservation, not only for their richness, but also their potential role in reducing isolation by serving as habitat bridges in the formation of a network of functionally connected areas, stepping stones assisting in the movement of fauna (Boscolo et al., 2008; Fischer and Lindenmayer, 2002; Martensen et al., 2012; Mueller et al., 2014). If all remnants smaller than 200 ha are considered, the mean isolation of remnants would decrease from over $9112 \mathrm{~m}$ to less than $1344 \mathrm{~m}$ (Ribeiro et al., 2009).

Many of the forest remnants surrounded by monocultures should be actively conserved because they provide key environmental services to society, especially when they are located in densely populated areas. The Brazilian Atlantic Forest is one example of a biome that has suffered intense pressure from human occupation. Approximately $88 \%$ of the original forest area has been lost, and nature reserves protect only $2.6 \%$ of it (Soares-Filho et al., 2014). Moreover, more than $80 \%$ of the remaining forest patches are smaller than 50 ha (Ribeiro et al., 2009). Indeed, large remnants of the Atlantic Forest are rare, and conservation of biodiversity will only be possible if these small- and medium-sized forest remnants can be protected and restored.

The massive changes suffered by forest remnants of tropical ecosystems have gradually led to their disruption and a decrease in the number of individuals of different plant species, especially late successional and very large-fruited trees (Karp et al., 2012; Magnago et al., 2014; Oliveira et al., 2008). A similar loss has been observed for animals of the various trophic levels (Canale et al., 2012; Gibson et al., 2013; Terborgh et al., 2001), although the true extent of such alterations in small patches is unknown. These changes can be viewed as a track record of disturbances that will eventually lead to the collapse of ecosystems (Rietkerk et al., 2004). In fact, ecosystems with low intactness have traditionally been ignored in conservation policies (Newbold et al., 2016). However, the investment in their restoration through adaptive management may be able to reverse the environmental changes, thus promoting the conservation of biodiversity and the provision of environmental services.

Many studies recommend the priorization of conservation or restoration only of those ecosystems that meet a minimum landscape natural cover criterion (Tambosi et al., 2014), often considered to be a minimum of $30 \%$ of the forest cover in a landscape in order to avoid the extinction of animal and plant species (Banks-Leite et al., 2014; Lima and Mariano-Neto, 2014), although Muylaert et al. (2016) report the decline of bat richness at such a low threshold. Such an approach can cause environmental decision makers to recommend the abandonment of numerous natural remnants which are considered useless for conservation, thus leaving them to continue on their course to collapse.

The effects of landscape attributes on fauna have been extensively studied for birds (Banks-Leite et al., 2014; Estavillo et al., 2013; Magioli et al., 2015; Martensen et al., 2012). However, little is known about the relationship between landscape and the species and functional groups of plants in forest remnants, yet there is a lack of studies considering the variability of ecosystem descriptors (Karp et al., 2012; Mühlner et al., 2012). Most of the studies which do exist have focused on plots within large, well conserved areas (Gibson et al., 2011; ter Steege et al., 2013). Rarely is the relationship between landscape and plant diversity studied within highly fragmented areas, where the forest cover and patch size are reduced, and where isolation and edge effects are more severe (Magnago et al., 2014; Rodríguez-Loinaz et al., 2012). These natural remnants are not necessarily a lost cause, however, although their ability to contribute to conservation and to provide environmental services will depend on their structural integrity and biodiversity (Ferraz et al., 2014; Honey-Rosés et al., 2013; Lopes et al., 2009). The present study was designed to promote the understanding of the effects of landscape on the richness of tree-like plants and their proportions; aspects considered included mode of seed dispersal and ecological category. An attempt was made to answer the following questions for a monoculture matrix region: (1) What is the influence of landscape structure on plant richness and the proportion of species of different ecological groups? (2) Is the plant richness different for sites with different amounts of forest cover? (3) Does the regional pool of species, distributed in several small disturbed patches, increase total richness above that provided by large areas of protected forest? We hypothesized an increase in overall richness, especially that of zoochoric species, non-pioneer species of the canopy, and understory species, with an increase in the forest coverage of the site, even if it has been subjected to anthropogenic influences; we further hypothesized that it would increase with connectedness. This is one of the few studies evaluating the role of remaining fragments in the conservation of plant diversity in highly fragmented landscapes dominated by intensive agriculture for many decades.

\section{Material and methods}

\subsection{Study site}

The study was conducted in the domain of a seasonal semideciduous forest of the Atlantic Forest in a broad area of the interior of the state of São Paulo in Brazil (Fig. 1), an area with Cwa climate (Alvares et al., 2013) and altitudes of 400-550 m above sea level. The studied landscapes cover $300 \mathrm{~km}$ in the N-S direction and 400 in the W-E direction. The average distance between sites and reference reserves is $140 \mathrm{~km}$. Since the colonial period, native forests have gradually given way to monoculture plantations -mainly coffee in the past, and sugarcane at present. This has led to intense devastation of the landscape since 1850 . The first forest inventories estimated a loss of more than $80 \%$ of the forests by the $1950 \mathrm{~s}$ 


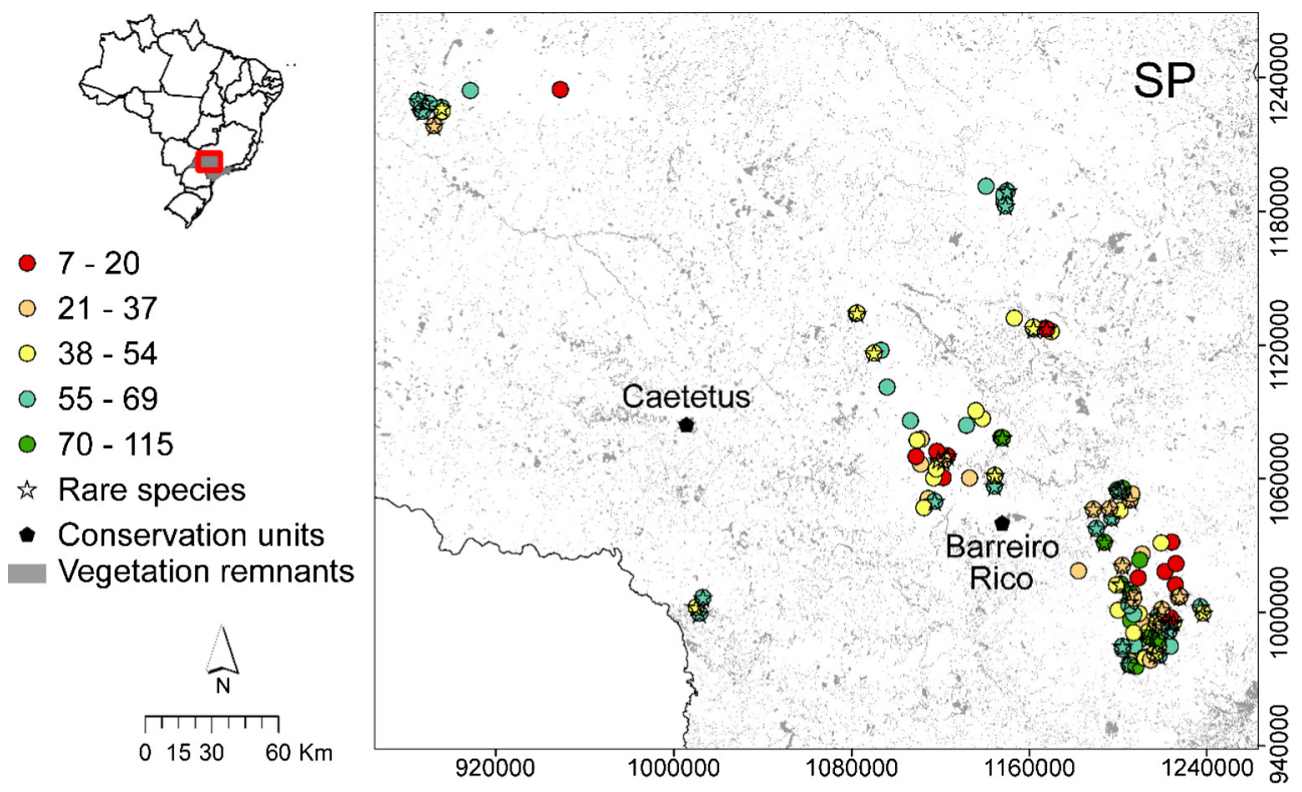

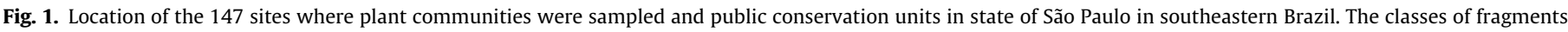
are presented in different colors according to the number of species. Forest patches marked with stars harboured rare species (those that occurred in only one patch).

(Victor et al., 2005). The remaining patches are highly heterogeneous, with varying status of conservation, connectivity and size, and have for decades been part of a matrix dominated by sugarcane, or, much less frequently, cultivated forests (Eucalyptus spp.), fruit crops (Citrus spp.) and cattle pastures. There is no precise historical record of the extent of these particular fragments, since the first aerial images date back to the 1960s and the fragmentation process is older (Victor et al., 2005). The predominance of the sugarcane matrix has homogenised the main anthropic factors, such as recurrent fires and the use of pesticides, which are known to have an noxious effect on natural areas (Goldemberg et al., 2008; Martinelli and Filoso, 2008). Most of the forest patches reflect the present state of most remnants of the interior Atlantic Forest and represent a reduced and disturbed fraction of the original cover (Joly et al., 2014), with more than $80 \%$ of the patches being smaller than 50 ha (Ribeiro et al., 2009).

\subsection{Plant data collection}

Among hundreds of rural properties included in the LERF (Laboratory of Ecology and Forest Restoration) environmental adequacy program, we randomly selected fragments based on the criterion of a common landscape dominated by sugarcane, in a wide geographical area in the State of São Paulo.

The sampling consisted of transects, hereafter called 'sampling sites', each one covering both edge and interior of each forest fragment. For each transect, a maximum period of four hours was invested (discounted the time to manually open tracks), although shorter periods were sufficient for very small fragments (i.e. $<1 \mathrm{ha}$ ). The time spent in each site was recorded as sample effort. Each track crossed the fragment in one or more directions and had no width limitation, making it possible to maximize species observation. Whenever an environmental difference was observed (especially moist, soggy or shallow soil), a new transect was initiated; each local subtype of forest (deciduous, semideciduous, riparian or paludiculous forest) was then related to the floristic list. Thus, in some fragments two tracks were made (eg, one track in dry soil and the other in soaked soil), and the total number of sites (147) exceeded the number of fragments (134) ranging from 1 to 287 ha (mean 35.9 ha, SD 47.2). Sampling took place during 2009 and 2010, with samples of 7380 arborescent individuals collected (shrubs, trees, palms, ferns and bamboos, with no distinction made for young and adult plants), considering a minimum height of $0.5 \mathrm{~m}$ (seedlings were not included). Species identification was conducted at the ESA herbarium (ESALQ/University of São Paulo), in Piracicaba in the state of São Paulo.

\subsection{Forest classification}

Plant species were classified into ecological groups according to type of dispersal (zoochoric, anemochoric or autochoric) and stage of succession (pioneer species, non-pioneer species of the canopy and understory specialist) (Martins and Rodrigues, 2002). The forest sites were also classified according to conservation status, with the following local descriptors calculated for each site: canopy continuity, stratification, hyperabundance of liana cover, presence of invasive herbaceous species and signs of the presence of cattle (Gerwing and Farias, 2000). Sites with little disturbance where conservation would require only the removal of eventual disturbing factors such as the prevention of cattle or control of herbs on forest edges, were classified as "partially disturbed", whereas those with greater structural changes, large gaps and hyperabundance of lianas were classified as "disturbed" (Rodrigues et al., 2011). Sites with no signs of disturbance were classified as "conserved'. An image of one of the sampled fragments can be seen in Appendix A, Fig. 1.

\subsection{Control sites}

Two reference sites of public reserves were used as "control areas" for this study, both correspond to large remnants of the seasonal semideciduous Atlantic Forest: (1) Caetetus Ecological Station (EEC; 2179 ha) in the municipalities of Gália and Alvinlândia (mean altitude $590 \mathrm{~m}$ ) and (2) Barreiro Rico Ecological Station (EBR; $1451 \mathrm{ha}$ ) in Anhembi (mean altitude $500 \mathrm{~m}$ ). The plant lists used of these reserves were available from previous floristic assessments, carried out more intensively in specific studies by other authors (Assumpção et al., 1982; Cesar, 1988; Durigan et al., 2000; Franco, 2002; Barreto, 2015). We resolved the synonymies of their species, which resulted in a list per reserve. 


\subsection{Landscape selection and calculation of habitat cover}

Before calculation of the landscape metrics, a map of land use and forest cover was generated (scale of 1:5000). Circular buffers of different sizes were defined around the sampled sites, measured from the centroid of the forest patch. For each site, buffers of three different radii were defined $(0.5,1$ and $1.5 \mathrm{~km})$. These radii correspond to the potential dispersal of plants within an area (Wu and Hobbs, 2007). We considered the area covered by forest within the buffer, making it possible to incorporate the fragment area for almost all fragments in the $1500 \mathrm{~m}$ buffer, since they are fragments of small to medium size. For each sampling site, the following landscape metrics were calculated: forest coverage; functional connectivity; slope of terrain.

Forest cover was considered to be the amount of habitat necessary for plants. This descriptor was estimated for each site using a vegetation cover map and dividing the total area of the circle defined by the buffer on the respective scale by the forest area within the buffer. Three classes of vegetation were used to indicate forest habitat: early forest, medium or advanced deciduous forest and transition to forested savanna. Connectivity was measured as the functional connectivity or the area between forest patches, with those closer than $50 \mathrm{~m}$ being considered connected. This cutoff distance is based on the movement of forest-dwelling animals and gap-crossing distance for seed dispersers in the Atlantic Forest (Uezu et al., 2005; Boscolo et al., 2008; Metzger et al., 2009). It corresponds to the distance seeds are dispersed from a seasonal semideciduous forest remnant (Bertoncini and Rodrigues, 2008). All metrics were calculated using VLATE extension in ArcGIS (Lang and Tiede, 2003).

\subsection{Data analysis}

The models designed included all of the different predictors defined as potentially important for the prediction of the frequency of different species and ecological groups: slope of the terrain, local and regional coverage of forest, and connectivity. The area of fragment was contemplated by the percentage of forest cover in circular buffers of different sizes $(0.5,1$ and $1.5 \mathrm{~km})$, measured from the centre of the sampled site. The response variables were the number of species of trees of different successional groups (pioneer species, non-pioneer species of the canopy, and understory specialists), mode of seed dispersal (autochory, anemochory and zoochory) and total number of species.

\subsubsection{GLM, quantile regressions and model selection}

All analyses performed for selection and evaluation of models included generalised linear models (glms) and quantile regressions. The data are very scattered, for this reason, quantile regressions applies to use. Predictor effects for plant attributes were based on slope-estimated values of regressions and their effect direction. Both glms and quantile regressions were constructed for the following response variables: absolute and relative values of the dispersal mode and position in succession. The number of species per site was also analysed as a response variable. For all buffers sizes, the richness used was the same. Because the absolute value of the dispersal mode, position in succession and total richness can be influenced by sampling effects, these were factored out using the residuals of these variables in a glm for each as a function of the sampling effort as new response variables, as the residue is the part not explained by the sample effort. The fact that the study does not have standardised effort prevents us from using richness in modeling, so the use of residual of richness. Thus, seven of the response variables were residuals (autochorics, anemochorics, zoochorics, pioneers, non-pioneers of the canopy, understory and total richness). All the predictors were standard- ised prior to modelling. For the response variables that were absolute numbers transformed into residuals, glms were concurred with Gaussian distribution and quantilic regressions through model selection via Akaike Information criteria. The data are very scattered, so quantile regressions applies to use. Because many of the landscape predictor variables were correlated to some degree, all the variables were recasted at $500 \mathrm{~m}$ and at $1000 \mathrm{~m}$ to remove the effect of nestedness. Fig. A2 (Appendix A), shows the correlation values before and after this procedure (Rhodes et al., 2009).

For each response variable, there were 10 concurrent models: the models containing the univariate effect of slope and functional connectivity and their quantile version $(1,2,3,4)$, the models accounting for forest cover and their quantile versions at $500 \mathrm{~m}$ (5 and 6) at $1000 \mathrm{~m} \mathrm{(7} \mathrm{and} \mathrm{8)} \mathrm{and} \mathrm{at} 1500 \mathrm{~m}$ (9 and 10); an eleventh model corresponding to no effects (function of 1) was also generated (11). Those models below Akaike information criterion dAICc $<2.1$ were considered to be plausible, but only when the no-effect model was not plausible. Model strength was evaluated by Akaike weights $(\mathrm{Wi})$. Model strength was assigned for each predictor within the model. Plausible models (AICc < 2.1) were validated by visual inspection and leverage evaluation.

\subsubsection{Alpha and gamma richness: Potential additional richness}

In order to reveal potential additional richness for anthropogenic sites in relation to those of conservation units, rarefaction analyses were performed for (1) all sites, (2) all sites plus both units of conservation (Barreiro Rico and Caetetus), (3) sites below the threshold of $20 \%$, of forest cover, (4) sites above the threshold of $20 \%$, (5) sites below the traditional threshold of $30 \%$ and (6) sites above the threshold of $30 \%$. Venn diagrams were constructed to identify the intersection of components (Chen, 2016). The sample rarefaction curve was constructed with 500 permutation with specaccum function in the vegan package of $\mathrm{R}$ (Oksanen et al., 2016).

\subsubsection{Redundancy constrained analysis (RDA) and multivariate analysis of variance: Variance partition with permutation}

Using presence/absence matrices for arborescent species across forests sites in the anthropogenic landscape, the extent of change in community composition among sites was compared by beta diversity decomposition in turnover and nestedness components (Baselga, 2010). The overall variance in species composition was studied through beta diversity indicators (Jaccard index for turnover and nestedness components) (Magurran, 1988). Rare species (those sampled only once) were also evaluated. The concentration of rare species in space was investigated by the Moran's I index using the SAM software (Rangel et al., 2010). A redundancy constrained analysis (RDA) was conducted to verify possible spatial structure and environmental influences on community composition (presence or absence of each species), with all predictors combined (both noncorrelated and standardised) and coordinates of sites as the spatial components; its significance was checked with 999 permutations. The predictors used for the environmental component were slope, accumulated slope-related flow, forest cover (with 500, 1000 and $1500 \mathrm{~m}$ buffers) and connectedness. Variance partition (function varpart) was used to check individual and shared components in relation to variance explained by space (geographic coordinates) and environmental predictors (relief and landscape). Statistical analyses were conducted using R 3.1.3 (R Development Core Team, 2016) and the following packages: bbmle (Bolker, 2016), quantreg (Koenker et al., 2016), betapart (Baselga et al., 2013) and vegan (Oksanen et al., 2016). 
2.6.4. Permutational multivariate analysis of variance and community composition

Community composition for different sites above and below the theoretical threshold values for remaining forest cover, both the $30 \%$ recommended by conservation scientists and the $20 \%$ actually found with long-standing agricultural use in Brazil, were compared for buffer areas of 1000 and $1500 \mathrm{~m}$. Permutations (999) were used to calculate the significance of differences between multivariate variance homogeneity on community composition using Jaccard dissimilarity (functions betadisper and permutest in $\mathrm{R}$ ).

\section{Results}

The field evaluation of the 147 sampling sites resulted in the classification of most remnants as "disturbed" (needing restoration; $95.2 \%)$, but some (4.1\%) were classified as "only partially degraded"; a single patch was considered 'conserved' $(0.7 \%)$.

The total richness varied from seven to 115 species per patch (mean 35.50, SD 20.25, median 52). Overall, 521 plant species were found distributed among the 147 sites. Most of these species were zoochoric (65\%), and almost half were canopy trees (47\%).

In total, 118 species (23\%) were found only once and were considered rare. The forest patches harbouring these species are shown in Fig. 1, while the frequency of rare species in the forest patches is shown in Table A3 (Appendix A). The distribution of these rare species did not show any apparent relation to spatial structure variables, suggesting that any forest patch can harbour a rare species (Table A4, Appendix A; P value for all distances $>0.05$ ).

The percentage of forest cover per site declined from $23 \%$ (variance 164 ) for a buffer of $500 \mathrm{~m}$ to $17 \%$ (var. 81) for $1000 \mathrm{~m}$ and $14 \%$ for $1500 \mathrm{~m}$ (var. 61). The connected area varied from zero (for patches that were not connected to another patch within a search distance of $50 \mathrm{~m}$ ) to 205 ha (mean $18.65 \mathrm{ha}$ ).

Some of the many plausible models relating landscape and environmental factors to response variables were quite strong.
Fig. 2 presents only the models that were more plausible than the no-effect model. The connected area accounted for the strongest association; it was related to number of pioneer species, proportion of pioneers and percentage of zoochorics. The slope influenced the number and proportion of zoochoric species. The forest cover was positively correlated with the percentage of non-pioneer species in the canopy for all landscape scales, whereas it was negatively correlated to total richness for the $500 \mathrm{~m}$ and positively correlated for $1000 \mathrm{~m}$ and 1500 scales.

For the regions studied, the majority of the sites found were located in landscapes with a low forest cover $(<20 \%)$ for sites with $1000 \mathrm{~m}$ and $1500 \mathrm{~m}$ buffers (Table A6, Appendix A). They were consequently represented by more transects per landscape category than were those with more forest cover. Integrating the 521 species from the sites sampled with the 310 species from the conservation units raised the regional pool of species to 589. Thus, human-modified landscapes did indeed contribute an additional richness of 290 species to the regional pool, an increase of more than $90 \%$ (Figs. 3a and 4). In relation to the successional category, most of these 290 species are non-pioneers of canopy species (40\%), followed by understorey specialists (25\%), unclassifieds (24\%) and pioneers (12\%). In the dispersion categories we observed zoochorics (66\%), anemochorics (19\%), autochorics (13\%) and unclassifieds ( $2 \%)$. Although sites with $\geq 30 \%$ forest cover revealed some 300 species, those with $<20 \%$ revealed some 400 species (Fig. 3b). More statistical details are given in Table A7, Appendix A.

Beta diversity analysis showed a strong turnover component (0.987), indicating the replacement of species along the landscape. At the same time, analysis showed a very weak nestedness component (0.004), pointing that the pools of sites with smaller numbers of species are not subsets of the pools at richer sites, for the overall variance explained by high Jaccard dissimilarities (0.9912). The Whittaker global beta dissimilarity was 9.35, representing the number of distinct compositional units in the landscape.

Constrained redundancy analysis (RDA) showed weak influences of both spatial and environmental predictors on plant community composition (adjusted $\mathrm{R}^{2}=0.0679, \mathrm{~F}=1.17, \mathrm{P}=0.016$ ).

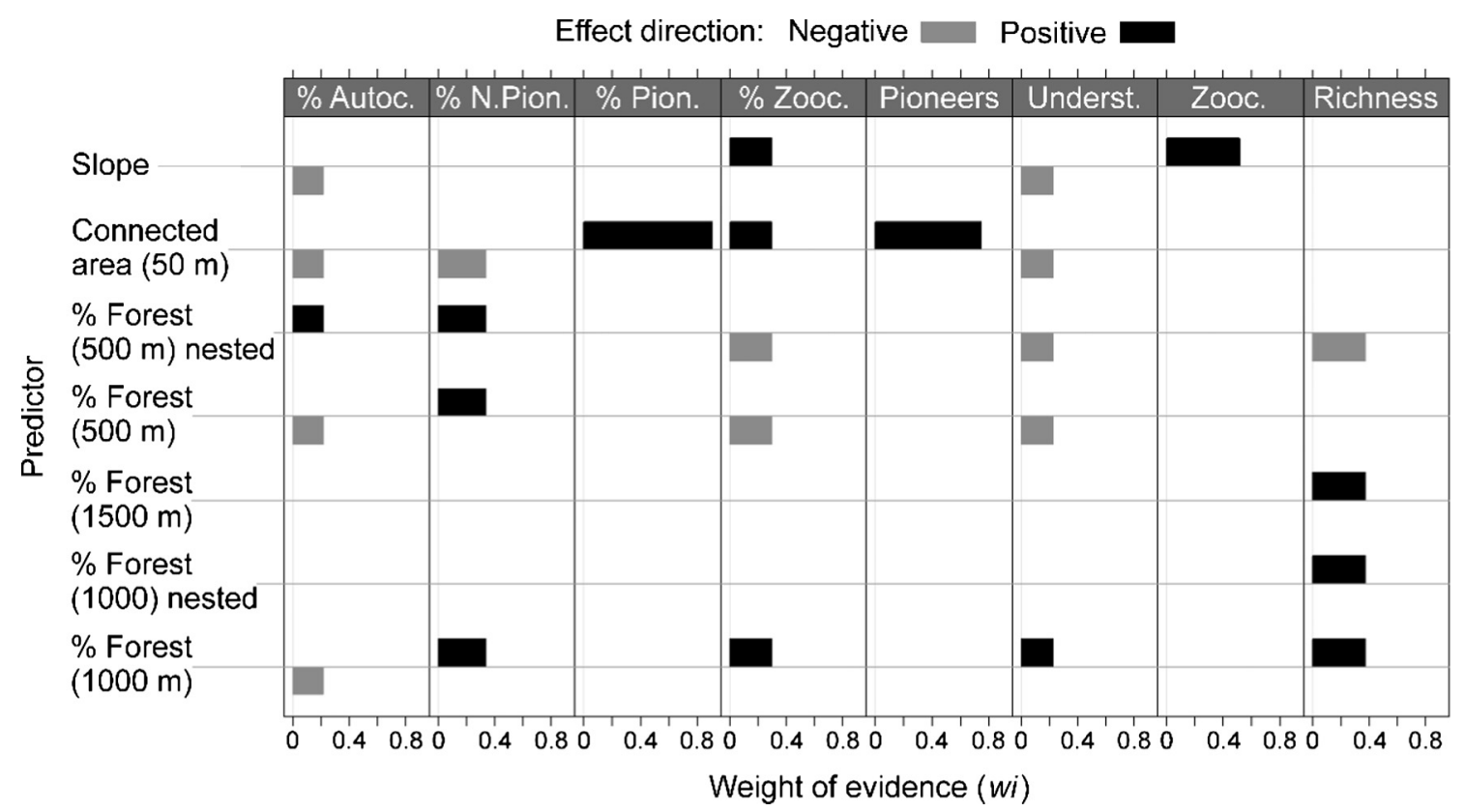

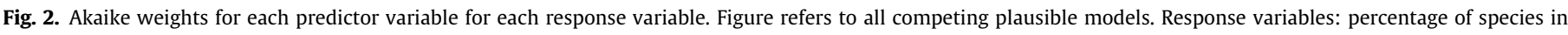

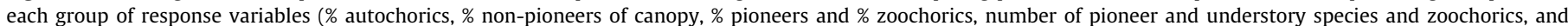

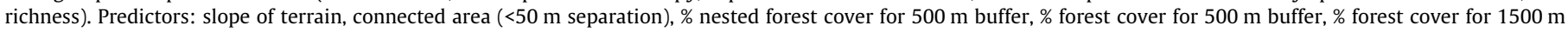
buffer, \% nested forest cover for $1000 \mathrm{~m}$ buffer, and \% forest cover for $1500 \mathrm{~m}$ buffer. 

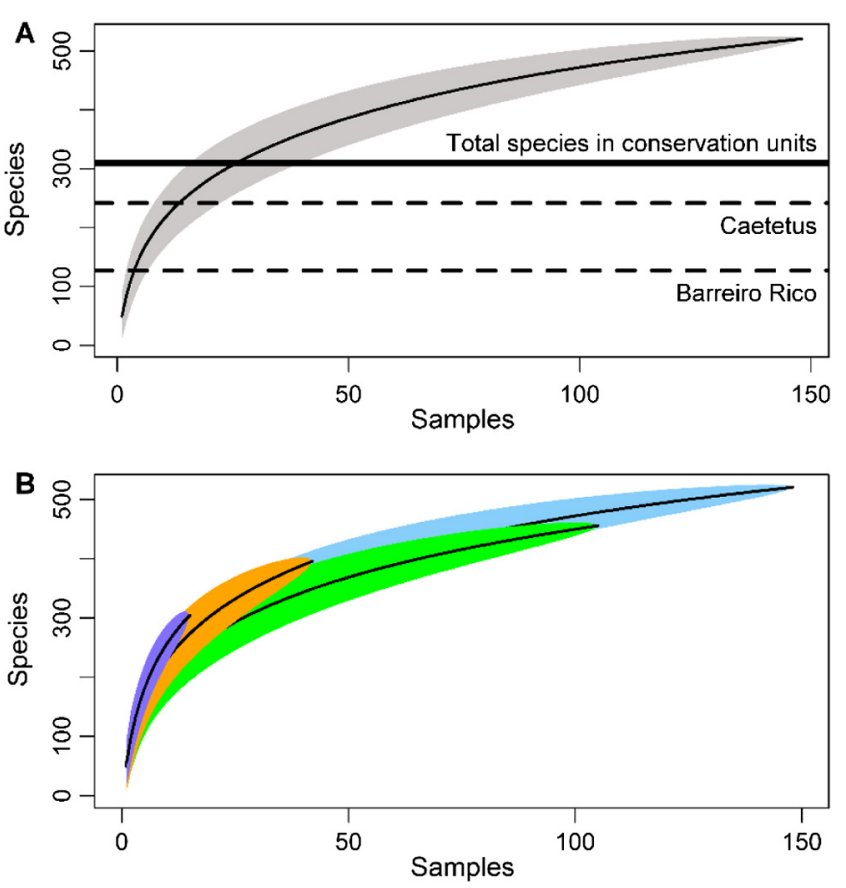

Fig. 3. Sample rarefaction curves for different situations. (a) Curve for the 147 forest patches compared with reference lines for the number of species found in public conservation reserves. (b) Light blue = all 147 forest patches; green $=$ patches with $<20 \%$ forest cover at $1000 \mathrm{~m}$ scale; orange = patches ranging from $<20 \% \leq$ forest cover but $<30 \%$ forest cover at $1000 \mathrm{~m}$ scale; dark blue $=$ patches with $\geq 30 \%$ forest cover at $1000 \mathrm{~m}$ scale.

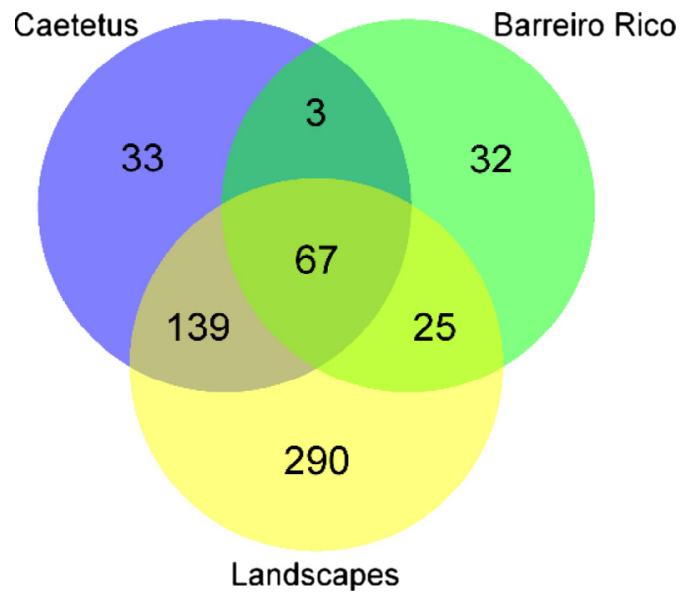

Fig. 4. Intersection of plant species found in the 147 sites with those found in the two main conservation units in the interior of the state of São Paulo in southeastern Brazil.

The fraction of variance for individual predictors resulting from variance partitioning was higher for the spatial component alone (adjusted $\mathrm{R}^{2}=0.057, \mathrm{~F}=5.65, \mathrm{df}=144, \mathrm{P}=0.001$ ) than for environmental variables (adjusted $\mathrm{R}^{2}=0.008, \mathrm{~F}=1.22, \mathrm{df}=139, \mathrm{P}=0.009$ ), and the shared variance for environmental variables structured in space was low (adjusted $\mathrm{R}^{2}=0.01047, \mathrm{~F}=1.17, \mathrm{P}=0.016$ ). The plot shows the score for each species (Fig. A5, Appendix A).

The composition of sites in landscapes above the $30 \%$ threshold of forest cover was positively influenced by slope-influenced flow, patch area, forest cover in a 500-m buffer area, and forest cover in $1000 \mathrm{~m}$ buffer, whereas the sites in landscapes with forest cover below the threshold responded more heterogeneously to these and other landscape factors (Fig. A5, Appendix A).

\section{Discussion}

The results of this study have shown that in the context of a 60to 100-year-old sugarcane monoculture matrix, important vegetal richness still survives in fragments of native forest; moreover, this richness can be related to landscape predictors. The possibility of conserving biodiversity in such forest fragments was seen in the large number of tree species (a total of more than 500) found in the 147 forest patches studied, a number which exceeds that of species found in units of public conservation by $90 \%$. Thus, biodiversity conservation does not depend solely on public reserves, because small remnants in the agricultural matrix have the potential for preserving an even greater number of species if actions are directed toward the conservation and restoration of these remnants. The great heterogeneity of the fragments in relation to the number of species, as well as the low nestedness and the presence of rare species showed that even smaller fragments can play a crucial role in the conservation of landscapes dominated by intensive agriculture. This richness of the flora in forest patches was important, even for sites with an extremely limited forest cover $(<20 \%)$.

The presence of non-pioneer canopy species in all patches may indicate a qualitative aspect to support conservation-restoration efforts. In addition to common disturbance factors affecting all the agricultural landscapes studied (occupancy by monoculture for several decades), the patterns based on landscape parameters indicate the stochastic permanence of certain species after specific events of disturbance in forest remnants, such as fire, the incursion of cattle, and the selective cutting of wood. The permanence of individuals of long-lived species (non-pioneer canopy species) in these disturbed remnants probably indicates that mortality occurs only after a long time lag after the disturbance (Metzger et al., 2009). The populations of the individuals sampled were probably went into decline after the death of their mother trees; yet, many adult representatives can be saved by restoration strategies, which should make possible the establishment of their seedlings. This feature of the fragments is also indicated by another qualitative component: the high proportion of zoochoric species. This shows the potential for recovery of the natural dynamics by the fauna in these fragments. The presence of these key species as seed sources may subsidise the restoration of ecological processes of these remnants if they are included in a broad program of ecological restoration.

It should be emphasized that the study was conducted in the lower end of the gradient of forest cover in the Atlantic Forest biome, with almost all sampled remnants highly disturbed. There is a pressing need for ecological restoration in most anthropogenic landscapes. Most conservation efforts nowadays ignore the smallor medium-sized remnants scattered in the predominantly agricultural matrix. At the same time the typical populations of mature ecosystems (both fauna and flora) actually found in the small remnants will face great difficulties in persisting (Galetti and Dirzo, 2013; Kurten, 2013). The maintenance of ecological interaction networks sustaining these ecosystems has become impossible, and as a result, their collapse is expected (Tabarelli et al., 2012). On the other hand, these remnants are located in the most populated regions, and the provision of basic ecosystem services for society depends on a program of environmental conservation based on regional planning (e.g. watersheds). The support of such ecosystems depends on the maintenance of biodiversity, which must be provided by effective actions for conservation and restoration (Rodrigues et al., 2009, 2011). Prioritizing the conservation or restoration of remnants according to a given criterion, e.g. the regional percentage of area covered by native vegetation, should not inhibit the adoption of initiatives aiming at the conservation and restoration of remnants in situations considered unfavourable, 


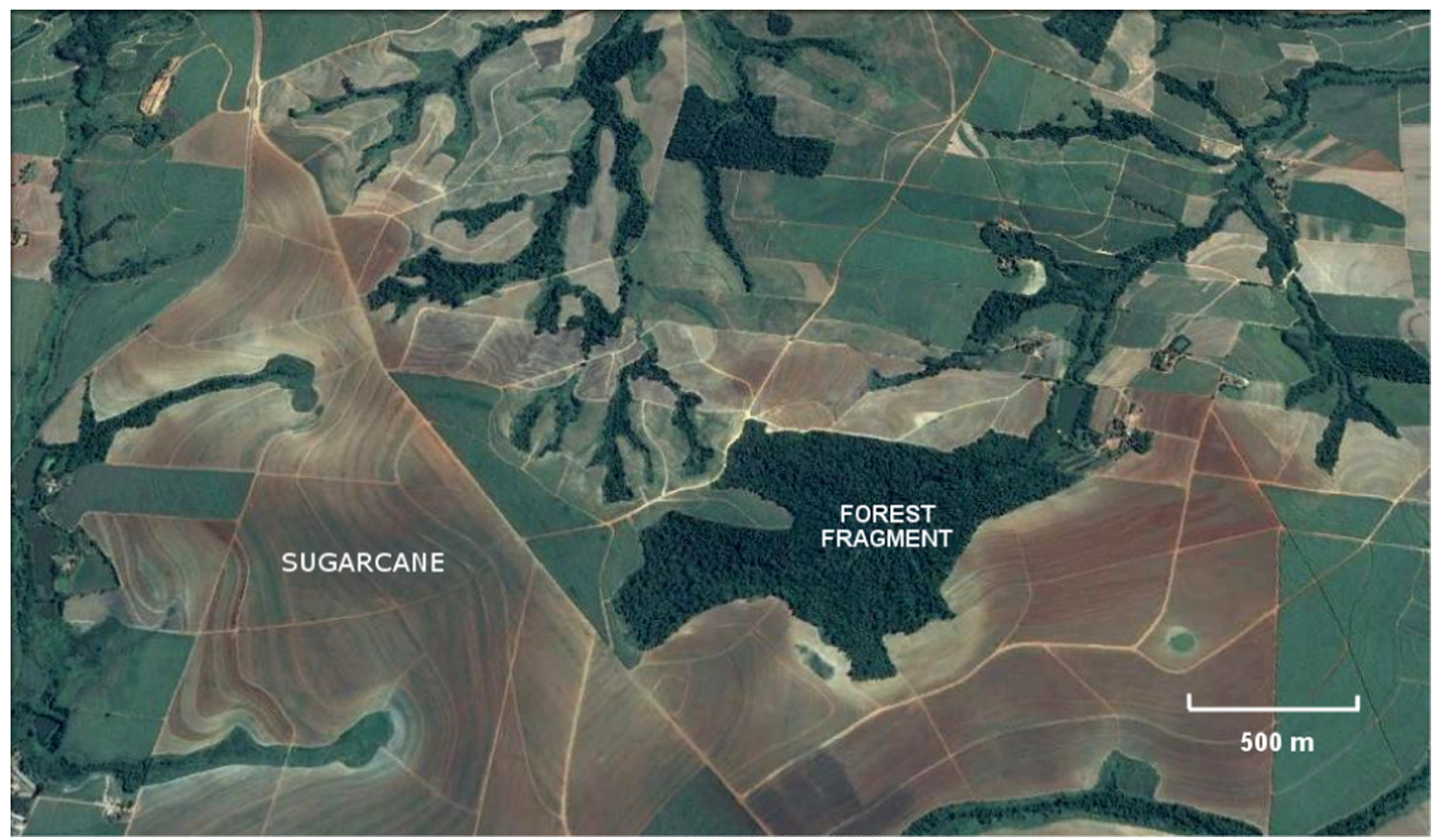

Fig. A1. Example of a forest fragment corresponding to a sampling site in the anthropogenic landscape dominated by sugarcane, state of São Paulo, Brazil.

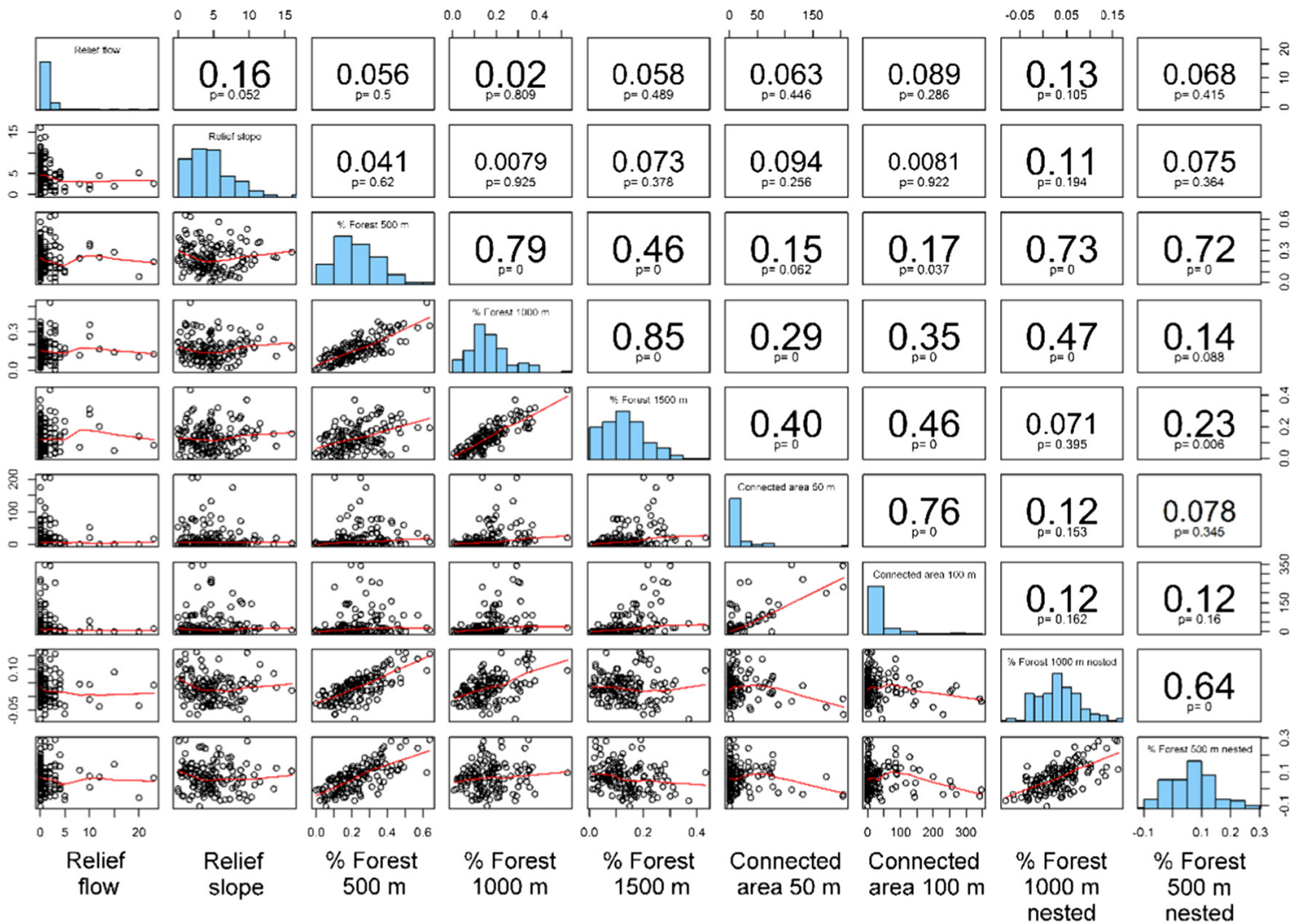

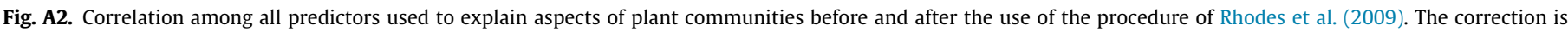
represented by the nested variables.

as in the case of landscapes with low coverage of native vegetation; it is important to keep this condition in mind because the remnants constitute a very large portion of what is left of the Atlantic Forest. It is essential to manage the remnants of ecosystems located on private properties adequately because they account for nearly $90 \%$ of the remaining Atlantic Forest (Ribeiro et al. 2009).

By restoring forests in anthropic landscapes and planning for each property and its surroundings in order to achieve at least $30 \%$ of regional coverage, it should be possible to maintain a large 


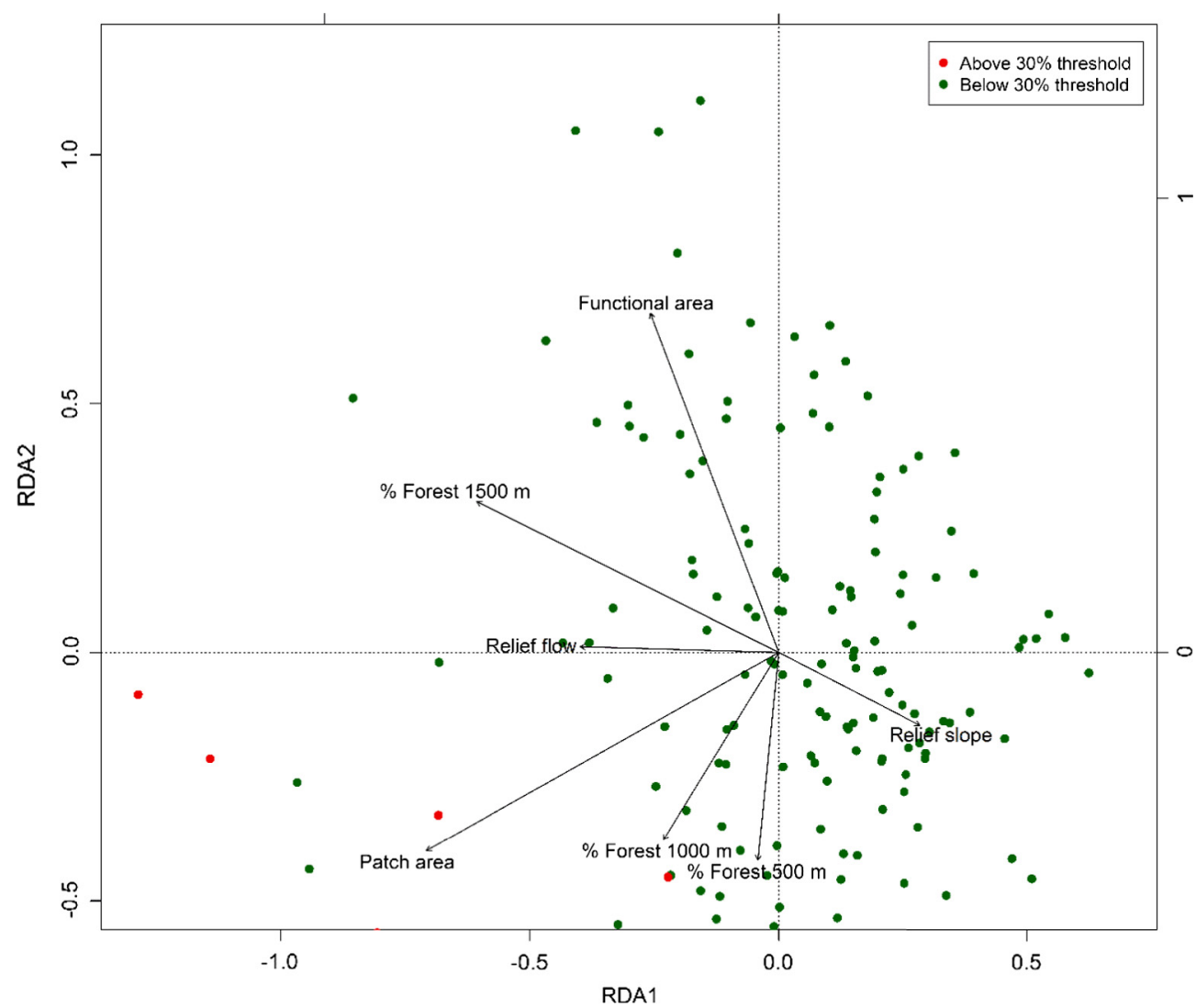

Fig. A5. Plot of constrained redundancy analysis for environmental components and plant community composition in a fragmented landscape.

Table A3

Prevalence of number of rare species (singletons) in forest remnants.

\begin{tabular}{lll}
\hline & Number of rare species & Number of patches \\
\hline & 1 & 27 \\
2 & 15 \\
3 & 6 \\
4 & 3 \\
& 5 & 1 \\
& 12 & 1 \\
Total & 14 & 1 \\
& 118 & 54 \\
\hline
\end{tabular}

number of species, as has been ascertained for the conservation of fauna (Banks-Leite et al., 2014) In these moderately deforested landscapes, the individuals remaining can significantly contribute to the maintenance of regional biodiversity (Hernández-Ruedas et al., 2014; Pardini et al., 2009). At the same time, the remnant patches in landscapes with little $(<20 \%)$ forest cover can play an important role in the conservation of diversity, and this contribution can be increased with programs of restoration. The network of disturbed fragments within landscapes of low intactness (Newbold et al., 2016) are the key to enable the conservation of biodiversity in anthropogenic landscapes, and ignoring them may lead to a reduction in overall biodiversity.

Given the association between agricultural production and environmental degradation and the need for the conservation of natural resources in agricultural landscapes, it is important to adopt strategies that promote the multifunctionality of the landscape, integrating the various functions harmoniously through agri cultural-environmental programs (Galler et al., 2015). Local managers should propose recommendations for more efficient use of cultivated areas and limit agricultural expansion (Phalan et al., 2016) so that the remaining natural areas can be preserved and degraded areas restored ecologically (Latawiec et al., 2015; Melo et al., 2013; Rodrigues et al., 2011; Vidal et al., 2016). However,

Table A4

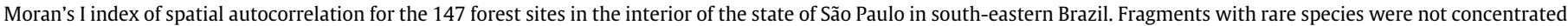
in space. Negative values of I indicate negative spatial autocorrelation and positive values indicate positive spatial autocorrelation.

\begin{tabular}{|c|c|c|c|c|c|}
\hline Distance classes & Moran's I & $P$ value & I (max) & $\mathrm{I} / \mathrm{I}(\max )$ & Expected overall \\
\hline 1 & -0.033 & 0.63 & 0.414 & -0.081 & -0.019 \\
\hline 2 & 0.018 & 0.71 & 0.467 & 0.038 & \\
\hline 3 & 0.074 & 0.28 & 0.67 & 0.111 & \\
\hline 4 & -0.104 & 0.11 & 0.935 & -0.112 & \\
\hline 5 & -0.023 & 0.50 & 0.921 & -0.025 & \\
\hline 6 & 0.007 & 0.85 & 0.303 & 0.022 & \\
\hline 7 & 0.042 & 0.34 & 0.469 & 0.09 & \\
\hline 8 & 0.007 & 0.88 & 0.417 & 0.018 & \\
\hline 9 & -0.048 & 0.38 & 0.853 & -0.056 & \\
\hline 10 & -0.131 & 0.07 & 1.502 & -0.087 & \\
\hline
\end{tabular}


Table A6

Percentage of forest patches in landscapes with different forest cover for different buffer radii.

\begin{tabular}{llll}
\hline Scale $(\mathrm{m})$ & \multicolumn{3}{l}{ Landscape forest amount (\%) } \\
\cline { 2 - 4 } & $<20$ & $20-30$ & $\geq 30$ \\
\hline \multirow{2}{*}{500} & 46 & 54 & 28 \\
\multirow{2}{*}{1000} & 72 & 29 & 10 \\
\multirow{2}{*}{1500} & 71 & & 3 \\
& 90 & 22 & 3 \\
& 78 & & \\
& 97 & &
\end{tabular}

the current policies of conservation focus only on alpha diversity and the protection of large remnants of vegetation that still preserve many species. The present study has proposed the importance of going beyond traditional theoretical assumptions (Tscharntke et al., 2012), by highlighting the importance of beta diversity in a wide range of landscapes, suggesting the existence of another perspective for conservation in agricultural properties that is not being contemplated. It seems likely that a strategy of beta diversity restoration and the connection of scattered patches can re-establish the gene flow, with enrichment of the remnants adopted when necessary. Once properly restored, these scattered remnants can undergo alpha restoration at the local level. It is argued here that the importance of such an approach for the restoration of diversity at a regional level is even necessary to enable the maintenance of diversity in large remnants and protected reserves. We thus advocate a broad-scale conservation and restoration policy that considers the entire regional landscape.

\section{Conclusions}

The present study has shown that degraded forest remnants within a matrix dominated by agriculture for many decades retain a great richness which can still be rescued. This richness exists even in landscapes with low forest cover $(<20 \%)$. This surprising richness should encourage restoration projects in forests harbouring large numbers of species, going beyond the numbers recorded in protected reserves. Many of these species are rare, but independent of spatial location, which suggests that species conservation depends on a regional-scale approach promoting the maintenance of the many scattered remnants in the landscape.

\section{Acknowledgments}

The authors would like to thank J. Assis the for preliminary discussions and acknowledge the financial assistance from the grants from the Brazilian Research Council (CNPq) to M.C. Ribeiro, R.R. Rodrigues and J.R.S.A. Mangueira (140825/2013-4), as well as those from the Foundation for the Support of Research of the State of São Paulo (FAPESP) for the grants to. R.L. Muylaert (2015/17739-4) and R.R. Rodrigues (2013/507185).

\section{Appendix A}

See Figs. A1, A3 and A5 and Tables A3, A4, A6 and A7.

\section{References}

Alvares, C.A., Stape, J.L., Sentelhas, P.C., De Moraes Gonçalves, J.L., Sparovek, G., 2013. Koppen's climate classification map for Brazil. Meteorol. Zeitschrift 22, 711-728. http://dx.doi.org/10.1127/0941-2948/2013/0507.

Arroyo-Rodriguez, V., Pineda, E., Escobar, F., Benitez-Malvido, J., 2009. Value of small patches in the conservation of plant-species diversity in highly fragmented rainforest. Conserv. Biol. 23, 729-739. http://dx.doi.org/10.1111/ j.1523-1739.2008.01120.x.

Arroyo-Rodríguez, V., Rös, M., Escobar, F., Melo, F.P.L., Santos, B.a., Tabarelli, M., Chazdon, R., 2013. Plant $\beta$-diversity in fragmented rain forests: testing floristic homogenization and differentiation hypotheses. J. Ecol. 101, 1449-1458. http:// dx.doi.org/10.1111/1365-2745.12153.

Assumpção, C.T., Leitão Filho, H.F., Cesar, O., 1982. Descrição das matas da Fazenda Barreiro Rico, Estado de São Paulo. Rev. Bras. Botânica 5, 67-82.

Banks-Leite, C., Pardini, R., Tambosi, L.R., Pearse, W.D., Bueno, A.A., Bruscagin, R.T. Condez, T.H., Dixo, M. Igari, A.T., Martensen, A.C., Metzger, J.P., 2014. Using ecological thresholds to evaluate the costs and benefits of set-asides in a biodiversity hotspot. Science (80) 345, 1041-1045.

Barlow, J., Gardner, T.A., Araujo, I.S., Avila-Pires, T.C., Bonaldo, A.B., Costa, J.E., Esposito, M.C., Ferreira, L.V., Hawes, J., Hernandez, M.I.M., Hoogmoed, M.S. Leite, R.N., Lo-Man-Hung, N.F., Malcolm, J.R., Martins, M.B., Mestre, L.aM. Miranda-Santos, R., Nunes-Gutjahr, a L., Overal, W.L., Parry, L., Peters, S.L. Ribeiro-Junior, M.a., da Silva, M.N.F., da Silva Motta, C., Peres, C.a., 2007. Quantifying the biodiversity value of tropical primary, secondary, and plantation forests. Proc. Natl. Acad. Sci. USA 104, 18555-18560. http://dx.doi. org/10.1073/pnas.0703333104.

Barreto, T.E., 2015. Padrões e processos que influenciam a dinâmica e a estrutura das Florestas Estacionais Semideciduais, SE, Brasil (PhD Thesis). Institute of Biology, State University of Campinas.

Baselga, A., 2010. Partitioning the turnover and nestedness components of beta diversity. Glob. Ecol. Biogeogr. 19, 134-143. http://dx.doi.org/10.1111/j.14668238.2009.00490.x.

Baselga, A., Orme, D., Villeger, S., Bortoli, J. De, Leprieur, F., 2013. Package "betapart": Partitioning beta diversity into turnover and nestedness components.

Bertoncini, A.P., Rodrigues, R.R., 2008. Forest restoration in an indigenous land considering a forest remnant influence (Avaí, São Paulo State, Brazil). For. Ecol. Manage. 255, 513-521. http://dx.doi.org/10.1016/j.foreco.2007.09.020.

Bolker, B., 2016. Package "bbmle": Tools for General Maximum Likelihood Estimation.

Boscolo, D., Candia-Gallardo, C., Awade, M., Metzger, J.P., 2008. Importance of interhabitat gaps and stepping-stones for lesser woodcreepers (Xiphorhynchus fuscus) in the Atlantic forest, Brazil. Biotropica 40, 273-276. http://dx.doi.org/ 10.1111/j.1744-7429.2008.00409.x.

Canale, G.R., Peres, C.A., Guidorizzi, C.E., Gatto, C.A.F., Kierulff, M.C.M., 2012. Pervasive defaunation of forest remnants in a tropical biodiversity hotspot. PLoS ONE 7, e41671. http://dx.doi.org/10.1371/journal.pone.0041671.

Cesar, O., 1988. Composição, florística e cliclagem de nutrientes em Mata Mesófila Semidecídua (Fazenda Barreiro Rico, Mun. Anhembi) (PhD Thesis). Institute of Biological Sciences, São Paulo State University.

Chazdon, R.L., Harvey, C.A., Komar, O., Griffith, D.M., Ferguson, B.G., MartínezRamos, M., Morales, H., Nigh, R., Soto-Pinto, L., van Breugel, M., Philpott, S. 2009a. Beyond reserves: A research agenda for conserving biodiversity in human-modified tropical landscapes. Biotropica 41, 142-153.

Chazdon, R.L., Peres, C.A., Dent, D., Sheil, D., Lugo, A.E., Lamb, D., Stork, N.E., Miller, S E., 2009b. The potential for species conservation in tropical secondary forests. Conserv. Biol. 23, 1406-1417. http://dx.doi.org/10.1111/j.1523-1739.2009. 01338.x.

Chen, H., 2016. Package "VennDiagram”: Generate high-resolution Venn and Euler plots.

Dahal, B.R., McAlpine, C.A., Maron, M., 2014. Bird conservation values of off-reserve forests in lowland Nepal. For. Ecol. Manage. 323, 28-38. http://dx.doi.org/ 10.1016/j.foreco.2014.03.033.

Dent, D.H., Wright, S.J., 2009. The future of tropical species in secondary forests: A quantitative review. Biol. Cons. 142, 2833-2843. http://dx.doi.org/10.1016/j. biocon.2009.05.035.

Durigan, G., Franco, G.a.D.C., Saito, M., Baitello, J.B., 2000. Estrutura e diversidade do componente arbóreo da floresta na Estação Ecológica dos Caetetus, Gália, SP. Rev. Bras. Botânica 23, 361-373.

Ehrlich, P.R., 2008. Key issues for attention from ecological economists. Environ. Dev. Econ. 13, 1-20. http://dx.doi.org/10.1017/S1355770X07004019.

Table A7

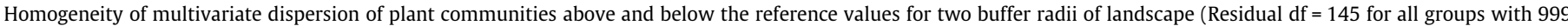
permutations).

\begin{tabular}{|c|c|c|c|c|c|c|c|}
\hline $\begin{array}{l}\text { Scale where \% forest was } \\
\text { measured }\end{array}$ & $\begin{array}{l}\text { Threshold } \\
\text { value }\end{array}$ & $\begin{array}{l}\text { Positive } \\
\text { eigenvalues }\end{array}$ & $\begin{array}{l}\text { Negative } \\
\text { eigenvalues }\end{array}$ & $\begin{array}{l}\text { Average distance to median above } \\
\text { the threshold }\end{array}$ & $\begin{array}{l}\text { Average distance to median below } \\
\text { the threshold }\end{array}$ & $\mathrm{F}$ & $\begin{array}{l}\mathrm{P} \\
\text { value }\end{array}$ \\
\hline $1500 \mathrm{~m}$ & $30 \%$ & 132 & 14 & 0.52 & 0.59 & 3.24 & 0.079 \\
\hline $1500 \mathrm{~m}$ & $20 \%$ & & & 0.58 & 0.59 & 0.02 & 0.86 \\
\hline $1000 \mathrm{~m}$ & $30 \%$ & & & 0.58 & 0.59 & 0.002 & 0.96 \\
\hline $1000 \mathrm{~m}$ & $20 \%$ & & & 0.59 & 0.58 & 0.35 & 0.52 \\
\hline
\end{tabular}


Estavillo, C., Pardini, R., Da Rocha, P.L.B., 2013. Forest loss and the biodiversity threshold: An evaluation considering species habitat requirements and the use of matrix habitats. PLoS ONE 8, 1-10. http://dx.doi.org/10.1371/journal. pone.0082369.

Farah, F.T., Rodrigues, R.R., Santos, F.aM., Tamashiro, J.Y., Shepherd, G.J., Siqueira, T. Batista, J.L.F., Manly, B.J.F., 2014. Forest destructuring as revealed by the temporal dynamics of fundamental species - Case study of Santa Genebra Forest in Brazil. Ecol. Indic. 37, 40-44. http://dx.doi.org/10.1016/j.ecolind.2013.09.011.

Ferraz, S.F.B., Ferraz, K.M.P.M.B., Cassiano, C.C., Brancalion, P.H.S., da Luz, D.T.a Azevedo, T.N., Tambosi, L.R., Metzger, J.P., 2014. How good are tropical forest patches for ecosystem services provisioning? Landsc. Ecol. 29, 187-200. http:// dx.doi.org/10.1007/s10980-014-9988-z.

Fischer, J., Lindenmayer, D.B., 2002. Small patches can be valuable for biodiversity conservation: Two case studies on birds in southeastern Australia. Biol. Cons 106, 129-136. http://dx.doi.org/10.1016/S0006-3207(01)00241-5.

Franco, G.A.D.C., 2002. Florística e fitossociologia de duas unidades do mosaico florestal da Estação Ecológica de Caetetus - Floresta Estacional Semidecidual, Gália - SP (PhD Thesis). "Luiz de Queiroz" College of Agriculture, University of São Paulo.

Galetti, M., Dirzo, R., 2013. Ecological and evolutionary consequences of living in a defaunated world. Biol. Cons. 163, 1-6. http://dx.doi.org/10.1016/j. biocon.2013.04.020.

Galler, C., von Haaren, C., Albert, C., 2015. Optimizing environmental measures for landscape multifunctionality: Effectiveness, efficiency and recommendations for agri-environmental programs. J. Environ. Manage. 151, 243-257. http://dx. doi.org/10.1016/j.jenvman.2014.12.011.

Gerwing, J.J., Farias, D.L., 2000. Integrating liana abundance and forest stature into an estimate of total aboveground biomass for an eastern Amazonian forest. J Trop. Ecol. 16, 327-335. http://dx.doi.org/10.1017/S0266467400001437.

Gibson, L., Lee, T.M., Koh, L.P., Brook, B.W., Gardner, T.a.a., Barlow, J., Peres, C.a Bradshaw, C.J.a., Laurance, W.F., Lovejoy, T.E., Sodhi, N.S., 2011. Primary forests are irreplaceable for sustaining tropical biodiversity. Nature 478, 378-381. http://dx.doi.org/10.1038/nature10425.

Gibson, L., Lynam, A.J., Bradshaw, C.J.A., He, F., Bickford, D.P., Woodruff, D.S Bumrungsri, S., Laurance, W.F., 2013. Near-complete extinction of native smal mammal fauna 25 Years after forest fragmentation. Science (80-) 341, 15081510. http://dx.doi.org/10.1126/science.1240495.

Goldemberg, J., Coelho, S.T., Guardabassi, P., 2008. The sustainability of ethanol production from sugarcane. Energy Policy 36, 2086-2097. http://dx.doi.org/ 10.1016/j.enpol.2008.02.028.

Hernández-Ruedas, M.A., Arroyo-Rodríguez, V., Meave, J.A., Martínez-Ramos, M. Ibarra-Manríquez, G., Martínez, E., Jamangapé, G., Melo, F.P.L., Santos, B.A. 2014. Conserving Tropical Tree Diversity and Forest Structure: The Value of Small Rainforest Patches in Moderately-Managed Landscapes. PLoS ONE 9, e98931. http://dx.doi.org/10.1371/journal.pone.0098931.

Honey-Rosés, J., Acuña, V., Bardina, M., Brozovic, N., Marcé, R., Munné, A., Sabater, S. Termes, M., Valero, F., Vega, Àl., Schneider, D.W., 2013. Examining the Demand for Ecosystem Services: The Value of Stream Restoration for Drinking Wate Treatment Managers in the Llobregat River, Spain. Ecol. Econ. 90, 196-205. http://dx.doi.org/10.1016/j.ecolecon.2013.03.019.

Immerzeel, D.J., Verweij, P.A., van der Hilst, F., Faaij, A.P.C., 2014. Biodiversity impacts of bioenergy crop production: A state-of-the-art review. GCB Bioenergy 6, 183-209. http://dx.doi.org/10.1111/gcbb.12067.

Joly, C.A., Metzger, J.P., Tabarelli, M., 2014. Experiences from the Brazilian Atlantic Forest: ecological findings and conservation initiatives. New Phytol. 204, 459473.

Karp, D.S., Rominger, A.J., Zook, J., Ranganathan, J., Ehrlich, P.R., Daily, G.C., 2012. Intensive agriculture erodes b-diversity at large scales. Ecol. Lett. 15, 963-970. http://dx.doi.org/10.1111/j.1461-0248.2012.01815.x.

Koenker, R., Portnoy, S., Ng, P.T., Zeileis, A., Grosjean, P., Ripley, B.D., 2016. Package “quantreg." doi: https://cran.r-project.org/web/packages/quantreg/quantreg. pdf.

Krauss, S.L., Sinclair, E.a., Bussell, J.D., Hobbs, R.J., 2013. An ecological genetic delineation of local seed-source provenance for ecological restoration. Ecol. Evol. 3, 2138-2149. http://dx.doi.org/10.1002/ece3.595.

Kurten, E.L., 2013. Cascading effects of contemporaneous defaunation on tropical forest communities. Biol. Cons. 163, 22-32. http://dx.doi.org/10.1016/j. biocon 2013.04 .025 .

Lang, S., Tiede, D., 2003. vLATE Extension für ArcGIS - vektorbasiertes Tool zur quantitativen Landschaftsstrukturanalyse.

Latawiec, A.E., Strassburg, B.B.N., Brancalion, P.H.S., Rodrigues, R.R., Gardner, T. 2015. Creating space for large-scale restoration in tropical agricultural landscapes. Front. Ecol. Environ. 13, 211-218. http://dx.doi.org/10.1890/ 140052.

Lee, T.M., Jetz, W., 2008. Future battlegrounds for conservation under global change. Proc. Biol. Sci. 275, 1261-1270. http://dx.doi.org/10.1098/rspb.2007.1732.

Lima, M.M., Mariano-Neto, E., 2014. Extinction thresholds for Sapotaceae due to forest cover in Atlantic Forest landscapes. For. Ecol. Manage. 312, 260-270. http://dx.doi.org/10.1016/j.foreco.2013.09.003.

Lopes, A.V., Girão, L.C., Santos, B.A., Peres, C.a., Tabarelli, M., 2009. Long-term erosion of tree reproductive trait diversity in edge-dominated Atlantic forest fragments. Biol. Cons. 142, 1154-1165. http://dx.doi.org/10.1016/j. biocon.2009.01.007.

Magioli, M., Ribeiro, M.C., Ferraz, K.M.P.M.B., Rodrigues, M.G., 2015. Thresholds in the relationship between functional diversity and patch size for mammals in the Brazilian Atlantic Forest. Anim. Conserv. 18, 499-511. http://dx.doi.org/ 10.1111/acv,12201.

Magnago, L.F.S., Edwards, D.P., Edwards, F.a.a., Magrach, A., Martins, S.V., Laurance, W.F., 2014. Functional attributes change but functional richness is unchanged after fragmentation of Brazilian Atlantic forests. J. Ecol. 102, 475-485. http://dx. doi.org/10.1111/1365-2745.12206.

Magurran, A.E., 1988. Ecological Diversity and Its Measurement. Springer, Netherlands. http://dx.doi.org/10.1007/978-94-015-7358-0.

Martensen, A.C., Ribeiro, M.C., Banks-Leite, C., Prado, P.I., Metzger, J.P., 2012 Associations of forest cover, fragment area, and connectivity with neotropical understory bird species richness and abundance. Conserv. Biol. 26, 1100-1111. http://dx.doi.org/10.1111/j.1523-1739.2012.01940.x.

Martin, P., Bullock, J., Newton, A., 2013. Carbon pools recover more rapidly than plant biodiversity in secondary tropical forests. Philos. Trans. R. Soc. B 280, 20132236. http://dx.doi.org/10.1098/rspb.2013.2236.

Martinelli, L.a., Filoso, S., 2008. Expansion of sugarcane ethanol production in Brazil: Environmental and social challenges. Ecol. Appl. 18, 885-898. http://dx.doi.org/ 10.1890/07-1813.1.

Martins, S.V., Rodrigues, R.R., 2002. Gap-phase regeneration in a semideciduous mesophytic forest, south - eastern Brazil 50661, pp. 1-12.

Melo, F.P.L., Arroyo-Rodríguez, V., Fahrig, L., Martínez-Ramos, M., Tabarelli, M., 2013. On the hope for biodiversity-friendly tropical landscapes. Trends Ecol. Evol. 28, 462-468. http://dx.doi.org/10.1016/j.tree.2013.01.001.

Metzger, J.P., Martensen, A.C., Dixo, M., Bernacci, L.C., Ribeiro, M.C., Teixeira, A.M.G., Pardini, R., 2009. Time-lag in biological responses to landscape changes in a highly dynamic Atlantic forest region. Biol. Cons. 142, 1166-1177. http://dx.doi. org/10.1016/j.biocon.2009.01.033.

Mueller, T., Lenz, J., Caprano, T., Fiedler, W., Böhning-Gaese, K., 2014. Large frugivorous birds facilitate functional connectivity of fragmented landscapes. J. Appl. Ecol. 51, 684-692. http://dx.doi.org/10.1111/1365-2664.12247.

Mühlner, S., Kormann, U., Schmidt-Entling, M.H., Herzog, F., Bailey, D., 2012. Structural versus functional habitat connectivity measures to explain bird diversity in fragmented orchards. J. Landsc. Ecol. 3, 52-64. http://dx.doi.org/ 10.2478/v10285-012-0023-2.

Muylaert, R.L., Stevens, R.D., Ribeiro, M.C., 2016. Threshold effect of habitat loss on bat richness in cerrado-forest landscapes. Ecol. Appl. 26, 1854-1867. http://dx. doi.org/10.1890/15-1757.1.

Neary, D.G., Ice, G.G., Jackson, C.R., 2009. Linkages between forest soils and water quality and quantity. For. Ecol. Manage. 258, 2269-2281. http://dx.doi.org/ 10.1016/j.foreco.2009.05.027.

Newbold, T. Hudson, L.N., Arnell, A.P. Contu, S., Palma, A.De., Ferrier, S., Hill, S.L.L. Hoskins, A.J., Lysenko, I., Phillips, H.R.P., Burton, V.J., Chng, C.W.T., Emerson, S., Gao, D., Pask-hale, G., Hutton, J., Jung, M., Sanchez-ortiz, K., Simmons, B.I. Whitmee, S., Zhang, H., 2016. Has land use pushed terrestrial biodiversity beyond the planetary boundary? A global assessment. Science (80-) 353, 288-291.

Norden, N., Chazdon, R.L., Chao, A., Jiang, Y.H., Vílchez-Alvarado, B., 2009. Resilience of tropical rain forests: Tree community reassembly in secondary forests. Ecol. Lett. 12, 385-394. http://dx.doi.org/10.1111/j.1461-0248.2009.01292.x.

Oksanen, J., Blanchet, F.G., Friendly, M., Kindt, R., Legendre, P., McGlinn, D., Minchin, P.R., Hara, R.B.O., Simpson, G.L., Solymos, P., Stevens, M.H.H., Szoecs, E., Wagner, H., 2016. Package "vegan". Commun. Ecol. ISBN 0-387-95457-0.

Oliveira, M.A., Santos, A.M.M., Tabarelli, M., 2008. Profound impoverishment of the large-tree stand in a hyper-fragmented landscape of the Atlantic forest. For. Ecol. Manage. 256, 1910-1917. http://dx.doi.org/10.1016/j.foreco.2008.07.014.

Pan, Y., Birdsey, R.a., Fang, J., Houghton, R., Kauppi, P.E., Kurz, W.a., Phillips, O.L., Shvidenko, A., Lewis, S.L., Canadell, J.G., Ciais, P., Jackson, R.B., Pacala, S.W., McGuire, a.D., Piao, S., Rautiainen, A., Sitch, S., Hayes, D., 2011. A large and persistent carbon sink in the world's forests. Science 333, 988-993. http://dx. doi.org/10.1126/science.1201609.

Pardini, R., Faria, D., Accacio, G.M., Laps, R.R., Mariano-Neto, E., Paciencia, M.L.B., Dixo, M., Baumgarten, J., 2009. The challenge of maintaining Atlantic forest biodiversity: A multi-taxa conservation assessment of specialist and generalist species in an agro-forestry mosaic in southern Bahia. Biol. Cons. 142, 11781190. http://dx.doi.org/10.1016/j.biocon.2009.02.010.

Phalan, B., Green, R.E., Dicks, L.V., Dotta, G., Feniuk, C., Lamb, A., Strassburg, B.B.N., Williams, D.R., Ermgassen, E.K.H.J.z., Balmford, A., 2016. How can higher-yield farming help to spare nature? Science (80-) 351, 450-451. http://dx.doi.org/ $10.1126 /$ science aad0055.

Poorter, L., Bongers, F., Aide, T.M., Almeyda Zambrano, A.M., Balvanera, P., Becknell, J.M., Boukili, V., Brancalion, P.H.S., Broadbent, E.N., Chazdon, R.L., Craven, D., de Almeida-Cortez, J.S., Cabral, G.A.L., de Jong, B.H.J., Denslow, J.S., Dent, D.H., DeWalt, S.J., Dupuy, J.M., Durán, S.M., Espírito-Santo, M.M., Fandino, M.C., César, R.G., Hall, J.S., Hernandez-Stefanoni, J.L., Jakovac, C.C., Junqueira, A.B., Kennard, D., Letcher, S.G., Licona, J.-C., Lohbeck, M., Marín-Spiotta, E., Martínez-Ramos, M., Massoca, P., Meave, J.A., Mesquita, R., Mora, F., Muñoz, R., Muscarella, R. Nunes, Y.R.F., Ochoa-Gaona, S., de Oliveira, A.A., Orihuela-Belmonte, E., PeñaClaros, M., Pérez-García, E.A., Piotto, D., Powers, J.S., Rodríguez-Velázquez, J., Romero-Pérez, I.E., Ruíz, J., Saldarriaga, J.G., Sanchez-Azofeifa, A., Schwartz, N.B. Steininger, M.K. Swenson, N.G. Toledo, M. Uriarte, M., van Breugel, M., van der Wal, H., Veloso, M.D.M., Vester, H.F.M., Vicentini, A., Vieira, I.C.G., Bentos, T.V., Williamson, G.B., Rozendaal, D.M.A., 2016. Biomass resilience of Neotropical secondary forests. Nature 530, 211-214. http://dx.doi.org/10.1038/ nature16512.

Putz, F.E., Blate, G.M., Redford, K.H., Fimbel, R., 2001. Tropical forest management and conservation of biodiversity: an overview. Conserv. Biol. 15, 7-20. 
R Development Core Team, 2016. R: A Language and Environment for Statistical Computing. $\mathrm{R}$ Found. Stat. Comput. Vienna Austria. doi:10.1038/sj. hdy.6800737.

Rangel, T.F., Diniz-filho, J.A.F., Bini, L.M., 2010. SAM: a comprehensive application for Spatial Analysis in Macroecology. Ecography (Cop.) 33, 46-50. http://dx.doi. org/10.1111/j.1600-0587.2009.06299.x.

Rey Benayas, J.M., Bullock, J.M., 2012. Restoration of biodiversity and ecosystem services on agricultural land. Ecosystems 15, 883-899. http://dx.doi.org/ 10.1007/s10021-012-9552-0.

Rhodes, J.R., McAlpine, C.A., Zuur, A.F., Smith, G.M., Ieno, E.N., 2009. GLMM applied on the spatial distribution of koalas in a fragmented landscape. In: Zuur, A.F., Ieno, E.N., Walker, N.J., Saveliev, A.A., Smith, G.M. (Eds.), Mixed Effects Models and Extensions in Ecology With R.. Springer, New York, pp. 469-492. http://dx. doi.org/10.1007/978-0-387-87458-6_21.

Ribeiro, M.C., Metzger, J.P., Martensen, A.C., Ponzoni, F.J., Hirota, M.M., 2009. The Brazilian Atlantic Forest: How much is left, and how is the remaining forest distributed? Implications for conservation. Biol. Cons. 142, 1141-1153. http:// dx.doi.org/10.1016/j.biocon.2009.02.021.

Rietkerk, M., Dekker, S.C., de Ruiter, P.C., van de Koppel, J., 2004. Self-organized patchiness and catastrophic shifts in ecosystems. Science 305, 1926-1929. http://dx.doi.org/10.1126/science.1101867.

Rodrigues, R.R., Gandolfi, S., Nave, A.G., Aronson, J., Barreto, T.E., Vidal, C.Y. Brancalion, P.H.S., 2011. Large-scale ecological restoration of high-diversity tropical forests in SE Brazil. For. Ecol. Manage. 261, 1605-1613. http://dx.doi. org/10.1016/j.foreco.2010.07.005.

Rodrigues, R.R., Lima, R.a.F., Gandolfi, S., Nave, A.G., 2009. On the restoration of high diversity forests: 30 years of experience in the Brazilian Atlantic Forest. Biol. Cons. 142, 1242-1251. http://dx.doi.org/10.1016/j.biocon.2008.12.008.

Rodríguez-Loinaz, G., Amezaga, I., Onaindia, M., 2012. Does forest fragmentation affect the same way all growth-forms? J. Environ. Manage. 94, 125-131. http:// dx.doi.org/10.1016/j.jenvman.2011.06.024.

Soares-Filho, B., Rajao, R., Macedo, M., Carneiro, A., Costa, W., Coe, M., Rodrigues, H., Alencar, A., 2014. Cracking Brazil's Forest Code. Science (80-) 344, 363-364. http://dx.doi.org/10.1126/science.1246663.

Sodhi, N.S., Koh, L.P., Clements, R., Wanger, T.C., Hill, J.K., Hamer, K.C., Clough, Y., Tscharntke, T., Posa, M.R.C., Lee, T.M., 2010. Conserving Southeast Asian forest biodiversity in human-modified landscapes. Biol. Cons. 143, 2375-2384. http:// dx.doi.org/10.1016/j.biocon.2009.12.029.

Solar, R.R.C., Barlow, J., Ferreira, J., Berenguer, E., Lees, A.C., Thomson, J.R., Louzada, J., Maués, M., Moura, N.G., Oliveira, V.H.F., Chaul, J.C.M., Schoereder, J.H., Vieira, I.C G., Mac Nally, R., Gardner, T.A., 2015. How pervasive is biotic homogenization in human-modified tropical forest landscapes? Ecol. Lett. 18, 1108-1118. http:// dx.doi.org/10.1111/ele.12494.

Tabarelli, M., Peres, C.A., Melo, F.P.L., 2012. The "few winners and many losers" paradigm revisited: emerging prospects for tropical forest biodiversity. Biol. Cons. 155, 136-140. http://dx.doi.org/10.1016/j.biocon.2012.06.020.

Tabarelli, M., Venceslau, A., Cezar, M., Paul, J., Peres, C.A., 2010. Prospects for biodiversity conservation in the Atlantic Forest: Lessons from aging humanmodified landscapes. Biol. Cons. 143, 2328-2340. http://dx.doi.org/10.1016/j. biocon.2010.02.005.

Tambosi, L.R., Martensen, A.C., Ribeiro, M.C., Metzger, J.P., 2014. A framework to optimize biodiversity restoration efforts based on habitat amount and landscape connectivity. Restor. Ecol. 22, 169-177. http://dx.doi.org/10.1111/ rec.12049.

ter Steege, H., Pitman, N.C.A., Sabatier, D., Baraloto, C., Salomão, R.P., Guevara, J.E., Phillips, O.L., Castilho, C. V, Magnusson, W.E., Molino, J.-F., Monteagudo, A., Núñez Vargas, P., Montero, J.C., Feldpausch, T.R., Coronado, E.N.H., Killeen, T.J., Mostacedo, B., Vasquez, R., Assis, R.L., Terborgh, J., Wittmann, F., Andrade, A., Laurance, W.F., Laurance, S.G.W., Marimon, B.S., Marimon, B.-H., Guimarães
Vieira, I.C., Amaral, I.L., Brienen, R., Castellanos, H., Cárdenas López, D. Duivenvoorden, J.F., Mogollón, H.F., Matos, F.D.D.A., Dávila, N., GarcíaVillacorta, R., Stevenson Diaz, P.R., Costa, F., Emilio, T., Levis, C., Schietti, J., Souza, P., Alonso, A., Dallmeier, F., Montoya, A.J.D., Fernandez Piedade, M.T. Araujo-Murakami, A., Arroyo, L., Gribel, R., Fine, P.V. a, Peres, C. a, Toledo, M., Aymard C, G. a, Baker, T.R., Cerón, C., Engel, J., Henkel, T.W., Maas, P., Petronelli, P., Stropp, J., Zartman, C.E., Daly, D., Neill, D., Silveira, M., Paredes, M.R., Chave, J., Lima Filho, D.D.A., Jørgensen, P.M., Fuentes, A., Schöngart, J., Cornejo Valverde, F., Di Fiore, A., Jimenez, E.M., Peñuela Mora, M.C., Phillips, J.F., Rivas, G., van Andel, T.R., von Hildebrand, P., Hoffman, B., Zent, E.L., Malhi, Y., Prieto, A., Rudas A., Ruschell, A.R., Silva, N., Vos, V., Zent, S., Oliveira, A. a, Schutz, A.C., Gonzales, T., Trindade Nascimento, M., Ramirez-Angulo, H., Sierra, R., Tirado, M., Umaña Medina, M.N., van der Heijden, G., Vela, C.I. a, Vilanova Torre, E., Vriesendorp, C., Wang, O., Young, K.R., Baider, C., Balslev, H., Ferreira, C., Mesones, I., TorresLezama, A., Urrego Giraldo, L.E., Zagt, R., Alexiades, M.N., Hernandez, L., Huamantupa-Chuquimaco, I., Milliken, W., Palacios Cuenca, W., Pauletto, D., Valderrama Sandoval, E., Valenzuela Gamarra, L., Dexter, K.G., Feeley, K., LopezGonzalez, G., Silman, M.R., 2013. Hyperdominance in the Amazonian tree flora Science 342, 1243092. doi: http://dx.doi.org/10.1126/science.1243092.

Terborgh, J., Lopez, L., Nuñez, P., Rao, M., Shahabuddin, G., Orihuela, G., Riveros, M., Ascanio, R., Adler, G.H., Lambert, T.D., Balbas, L., 2001. Ecological meltdown in predator-free forest fragments. Science 294, 1923-1926. http://dx.doi.org/ 10.1126/science.1064397.

Tscharntke, T., Tylianakis, J.M., Rand, T.A., Didham, R.K., Fahrig, L., Batáry, P., Bengtsson, J., Clough, Y., Crist, T.O., Dormann, C.F., Ewers, R.M., Fründ, J., Holt, R D., Holzschuh, A., Klein, A.M., Kleijn, D., Kremen, C., Landis, D.A., Laurance, W. Lindenmayer, D., Scherber, C., Sodhi, N., Steffan-Dewenter, I., Thies, C., van der Putten, W.H., Westphal, C., 2012. Landscape moderation of biodiversity patterns and processes - eight hypotheses. Biol. Rev. 87, 661-685. http://dx.doi.org/ 10.1111/j.1469-185X.2011.00216.x.

Turner, I.M., Corlett, R.T., 1996. The conservation value of small, isolated fragments of lowland tropical rain forest. Trends Ecol. Evol. 11, 330-333. http://dx.doi.org/ 10.1016/0169-5347(96)10046-X.

Uezu, A., Metzger, J.P., Vielliard, J.M.E., 2005. Effects of structural and functional connectivity and patch size on the abundance of seven Atlantic Forest bird species. Biol. Cons. 123, 507-519. http://dx.doi.org/10.1016/j.biocon.2005. 01.001.

Van Breugel, M., Hall, J.S., Craven, D., Bailon, M., Hernandez, A., Abbene, M., Van Breugel, P., 2013. Succession of ephemeral secondary forests and their limited role for the conservation of floristic diversity in a human-modified tropical landscape. PLoS ONE 8. http://dx.doi.org/10.1371/journal.pone.0082433.

Victor, M.A.M., Cavalli, A.C., Guillaumon, J.R., Filho, R.S., 2005. Cem anos de devastação: revisitada 30 anos depois. Brasília.

Vidal, C.Y., Mangueira, J.R., Farah, F.T., Rother, D.C., Rodrigues, R.R., 2016 Biodiversity conservation of forests and their ecological restoration in highlymodified landscapes. In: Gheler-Costa, C., Lyra-Jorge, M.C., Martins Verdade, L. (Eds.), Biodiversity in Agricultural Landscapes of Southeastern Brazil. De Gruyter Open, pp. 137-150. http://dx.doi.org/10.1515/9783110480849-010.

Wright, S.J., 2005. Tropical forests in a changing environment. Trends Ecol. Evol. 20, 553-560. http://dx.doi.org/10.1016/j.tree.2005.07.009.

Wright, S.J., Muller-Landau, H., 2006. The Uncertain Future of Tropical Forest Species 1. Biotropica 38, 443-445.

Wu, J., Hobbs, R., 2007. Landscape ecology: the state-of-the-science. In: Wu, J., Hobbs, R. (Eds.), Key Topics in Landscape Ecology. Cambridge University Press, Cambridge, pp. 271-287.

Zhang, L., Dawes, W.R., Walker, G.R., 2001. Response of mean annual evapotranspiration to vegetation changes at catchment scale. Water Resour. Res. 37, 701-708. http://dx.doi.org/10.1029/2000WR900325. 